\title{
WHAT IS INVARIANT? ON THE POSSIBILITY AND PERSPECTIVES OF THE EVOLUTIONARY THEOLOGY
}

\section{Introduction}

In the contemporary natural sciences, the evolution based on the Darwinian mechanism of natural selection is a universally accepted scenario for the origin and development of life in the Universe. The biological evolution fits into the broader picture of the standard cosmological model in which the history of life constitutes part of the history of the Universe from its very beginning, that is, from the moment of the Big Bang. The acceptance of the theory of evolution leads to a major change in the ontology of the Universe from the static one implied by the pre-scientific picture of the world to the dynamical one where the laws of nature do have the power to bring forth self-organization and the increase of complexity which in case of the human brain is believed to have reached its maximum. Such state of affairs challenges the pre-scientifically conditioned theology and religious thinking in general. Unfortunately, their irrational claims to pure objectivity often backfire with the atheistic arguments denying the existence of God the Creator who bestows order on nature in the act of creation ${ }^{2}$. While having no logical value whatsoever these arguments resonate quite broadly by means of their rhetorical power thus rendering the idea of locating theology within the evolutionary conceptual framework a risky and untrustworthy enterprise.

The main goal of this paper is to introduce, review and critically assess the actual status of research resulting from incorporating the evolutionary picture of the world into theology. This spans what can be now legitimately called the paradigm of the evolution-

1 Ks. dr hab. Wojciech P. Grygiel FSSP, Katedra Filozofii Przyrody, Wydział Filozoficzny, Uniwersytet Papieski Jana Pawła II w Krakowie. Adres do korespondencji: 31-002 Kraków, ul. Kanonicza 9; e-mail: wojciech.grygiel@ upjp2.edu.pl.

2 Richard Dawkins, The God Delusion (London-Toronto-Sydney-Auckland-Johannesburg, 2006). 
ary theology. The use of the term paradigm in theology appears explicitly in the works of Ian Barbour ${ }^{3}$ and reflects that of Thomas Kuhn in his analysis of the scientific rationality. Accordingly, a theological paradigm denotes in the broadest sense a certain tradition of the theological research with precisely defined methodological, epistemological and ontological assumptions. The scholastic theology with the philosophy of St. Thomas Aquinas as the conceptual foundation would qualify as a good example in this regard. Although the beginnings of the evolutionary theology reach back to works of Teilhard de Chardin and Karl Rahner, the major contribution to the its establishment and development comes from the works of such scholars as Arthur Peacocke, John Haught, Dennis Edwards, Francisco J. Ayala, and Michał Heller. It turns out that this paradigm has already made its way into several key areas of theology such as, for instance, creation, theological anthropology (original sin, evil) and the Holy Trinity and is also listed as an encyclopedic entry ${ }^{4}$. The evolutionary theology may call for a marked reinterpretation and revision of some of the theological formulations which have been adopted as the fundamental tenets of faith.

It does not mean, however, that these tenets will have to be dropped entirely but some conceptual contents that they embrace may not pertain to the revealed truth but be mere artifacts of the human mind (anthropomorphisms) and, ultimately, they may have to be eliminated. This accords with the famous urge of John Paul II who insisted that "science can purify religion from error and superstition and religion can purify science from idolatry and false absolutes"5. More precisely, the replacement of the pre-scientific static picture of the world with the dynamic one consonant with the evolutionary scenarios should help to demonstrate which components of the theological expression relate the objective theological truth and which are only artifacts of the mythical representations of reality. Since a vast body of the theological expression necessitates such a scrutiny, only three topics will be handled: (1) general methodological concerns, (2) natural theology and (3) two systematic issues, namely, the original sin and the problem of evil. It will be eventually argued the evolutionary theology offers an intriguing perspective for the deepened conceptual penetration of the Divine essence and thus to the tightening of the intimacy with the One who is the source of all being. Also, a new model of the dynamic growth of theology based on the non-linear theory of dynamical systems will be proposed.

\section{Evolutionary theology}

Before any tenets of faith are subjected to the evolution induced reinterpretation, a preliminary methodological inquiry is fitting in order to outline the precise conditions of

3 Ian G. Barbour, Mity, modele, paradygmaty (Kraków, 1984), p. 174-179.

4 Niels Henrik. Gregersen, "Evolutionary theology", in: Encyclopedia of Sciences and Religions, ed. Anne L.C. Runehov, Lluis. Oviedo, Dordecht (Netherlands, 2013), p. 809-817.

5 John Paul II, "A Letter to the Reverend George V. Coyne, S.J., Director of the Vatican Observatory", in: Physics, Philosophy and Theology: A Common Quest for Understanding, ed. Robert John Russell, William R. Stoeger, S.J., George V. Coyne, S.J. (Vatican City State: Vatican Observatory, 2000), p. M1-M14. 
carrying out any reinterpretative efforts. As a scientific discipline, theology is chiefly concerned with the conceptual exposition of the content of revelation. Since it is always a human being that is the recipient of the revealed message, theology involves the relation between man and God: the meeting of the human mind with the revealed content ${ }^{6}$. In order that this content can be expressed, a conceptual framework must be used. This means that the theological discourse engages a delicate balance between the subjective and the objective, that is, how much of a human factor contributes to the final formulation. Consequently, the absolutely objective theological cognition becomes impossible. This idea was boldly articulated by Karl Rahner who insisted on the subject - relativised transmission and acceptance of the tenets of faith ${ }^{7}$. Moreover, the theological expression can never escape the significant tension between the finite character of the conceptual basis and the infinity of God indicating that concepts can never reach the Divine essence in a literal sense but only by means of analogy (metaphor). In other words, this is how far the positive claims of the theological discourse can reach.

In regards to the conceptual framework, every theology assumes a certain picture of the world, that is, an array of general beliefs on the structure of the Universe, the nature of man and the nature of human cognition. In such a case, religious beliefs involve elements of both religious and non-religious origin indicating that religion is always culturally conditioned and the means to adjust the non-religious component lie outside of its competence $^{8}$. This mostly concerns the changing picture of the world with the development of sciences so that this picture can be kept up to date with the most accurate knowledge of the real structure of the Universe. Since the religious beliefs must out of necessity be founded on truth or, more precisely, lie in its closest possible proximity, the constant refinement of the picture of the world seems to be of prime importance for their credibility ${ }^{9}$. It has been already clearly articulated by St. Basil that knowing more about the Universe leads to the constant enrichment of the conceptual foundation of theology whereby more adequate analogies can be constructed to refract the Divine essence ${ }^{10}$. In other words, theology can change as a doctrine although the revealed truths remain invariable.

The reliance of the theological expression on the picture of the world constitutes the proper methodological foundation for the paradigm of the evolutionary theology as the central theme of this study. By stating that theology is evolutionary one does not mean the relativization of the Divine truths but that the theological expression shifts its conceptual basis from the pre-scientific static picture of the world to a picture in which the

6 Vatican II, Dei Verbum, Art. 11, 12.

7 Karl Rahner, “Anthropologie (theologische)", in: Lexikon für Theologie und Kirche, ed. Josef Höfer, Karl Rahner (Freiburg/Br., 1957-67), col. 618-627.

8 Michał Heller, „Naukowy obraz świata a zadanie teologa”, in: Obrazy świata $w$ teologii $i$ w naukach przyrodniczych, ed. Michał Heller, Stanisław Budzik, Stanisław Wszołek (Tarnów, 1996), p. 13-27; Zbigniew Liana, „Teologia a naukowe obrazy świata, in: Wiara i nauka, ed. J. Mączka (Kraków, 2010), p. 69-90.

9 Augustine, De Genesi ad litteram I, 19-20; PL 34, 260 f.

10 Basil, De legendis libris Gentilium, PG 31, 565 and 568. 
most basic ontology is dynamic ${ }^{11}$. In its light, the currently observed great complexity of the living organisms is due to the process of their gradual evolution from simpler forms with the natural selection as its main mechanism ${ }^{12}$. The dynamical character of evolution, however, is not a novelty brought into science with this particular theory but it has already entered the physical description with the advent of the classical mechanics.

The mode of engaging the evolutionary picture of the world in the theological discourse will now be illustrated by a telling but somewhat controversial example. It seems quite surprising that in his exposition of the basic assumptions of the evolutionary theology Denis Edwards heavily accents the relational ontology as central to the evolutionary picture of the world by gleaning it not from the nature of reality at the level of the fundamental laws but from the phenomenal level emerging from the interactions of highly organized structures such as conscious living organisms, that is, human beings ${ }^{13}$. The detailed studies of the dynamical systems described by non-linear differential equations clearly demonstrate that the relationality responsible for the interaction among evolutionary competing organisms follows from the specific properties of these equations designated by a common term of the deterministic chaos ${ }^{14}$. Consequently, the question of the nature of the fundamental ontology concerns rather the mathematical structures of the fundamental level called in physics the Planck level and not the observable level of the biological phenomena. If one attempts to reformulate the theological expression by adopting the evolutionary picture of the world, one should base it on the concepts proper to the fundamental level of reality. Of course, some implications of the emergent structures could be taken into account at a later stage as supplementary to what has been established as fundamental.

Interestingly enough, however, the question of the relationality of ontology of reality at the fundamental level turns out to be a major issue in the philosophy of physics ${ }^{15}$. It is currently believed that this relationality is most properly reflected in the category theory. This highly abstract mathematical framework rests on the priority of relations (morphisms) with respect to objects and has been suggested to constitute a fundamental ontology referred to by Michał Heller as the category field ${ }^{16}$. This is the updated version of his older idea of the formal field or the field of rationality ${ }^{17}$. As a result, Edwards' claim that the relationality of the fundamental ontology is refracted in the relational character

11 Józef Turek, "Filozoficzno-światopoglądowe implikacje dynamicznego obrazu wszechświata”, in: Obrazy świata w teologii $i$ w naukach przyrodniczych, ed. Michał Heller, Stanisław Budzik, Stanisław Wszołek, p. 125-145.

12 Francisco J. Ayala, Dar Karola Darwina dla nauki i religii (Warszawa, 2009).

13 Denis Edwards, Bóg ewolucji: teologia trynitarna (Kraków, 2016), p. 40-54.

14 Wesley J. Wildman, Robert John Russell, "Chaos: A Mathematical Introduction with Philosophical Reflections", in: Chaos and Complexity: Scientific Perspectives on Divine Action, ed. Robert John Russell, Nancey Murphy, Arthur R. Peacocke, (Vatican City State, 1995), p. 49-90.

15 Steven French, The Structure of the World: Metaphysics and Representation (Oxford University Press: Oxford, 2014).

16 Michał Heller, "The field of rationality and category theory", in: Mathematical Structures of the Universe, ed. Michał Eckstein, Michał Heller, Sebastian Szybka (Kraków, 2014), p. 441-457.

17 Michał Heller, Uchwycić przemijanie (Kraków, 1997), p. 236-238. 
of the evolutionary processes within the biosphere does not seem to be well justified. And, more importantly, it does not to be a proper candidate to infer its relevance to the relationally conceived Trinitarian theology as exemplified by the theology of Richard of St. Victor and that of contemporary thinkers such as Walter Kasper to which Edwards makes numerous references ${ }^{18}$. Since these theologies involve the notion of a person as central to the nature of the Trinity, a significant anthropomorphization may additionally occur in the process of matching the network of the interpersonal relations within a given society with the relations taking place within the Trinity.

\section{How intelligent is the intelligent design?}

In the fourth proof of the existence of God or, more accurately, the fourth way to God, St. Thomas Aquinas stipulates that God's existence as the most perfect being is evident from the degrees of perfection ${ }^{19}$. If the created order exhibits perfection, however, it is only by means of participation in the ultimate perfection of $\operatorname{God}^{20}$. Although according to St. Thomas creation is a relation and not a imposition of forms on a preexisting matter by an intelligent designer ${ }^{21}$, the created order still reflects the Divine ideas as its shares in the perfection of God. The argument from perfection was heavily exploited by William Payley in his famous polemics with the theory of evolution at the early stage of its development. Payley contrasted the allegedly purposeful and ordered Divine creative activity with the probabilistic character of the evolutionary scenarios that rely on chance as their fundamental principle ${ }^{22}$. Hence, he concluded, evolution contradicts the Divine creation.

The detailed studies of the nature of the evolutionary processes of bringing forth complexity in the Universe, however, reveal features of these processes that do not coincide with the idea of a design resulting from the purposeful activity of a designer. This is particularly evident in the specificity of the natural selection that brings forth novelty not by means of the optimization of a new project but by means of slow modifications of the existing structures. In short, the novelty resulting from the natural selection is imperfect. For instance, this imperfection appears in the structure of the human brain that could

18 Edwards, Bóg ewolucji: teologia trynitarna, p. 34-40; Walter Kasper, The God of Jesus Christ (New York, 1976), p. 310.

19 Thomas Aquinas, Summa Theologiae I, q. 2, a. 3.

20 Thomas Aquinas, Summa Contra Gentiles III, 64, 9: "Res autem participat divinam bonitatem per modum similitudinis, inquantum ipsae sunt bona. Id autem quod est maxime bonum in rebus causatis, est bonum ordinis universi, quod est maxime perfectum, tu philosophus dicit: cui etiam consonat Scriptura divina, Gen. 1., cum dicitur, vidit Deus quae fecerat, et erat valde bona, cum de singulis operibus dixisset simpliciter quod erat bona".

21 Thomas Aquinas, De Potentia Dei, q. 3, a. 3: "Et ideo dicendum est, quod creatio potest sumi active et passive. Si sumatur active, sic designat Dei actionem, quae est eius essentia, cum relatione ad creaturam; quae non est realis relatio, sed secundum rationem tantum. Si autem passive accipiatur, cum creatio, sicut iam supra dictum est, proprie loquendo non sit mutatio, non potest dici quod sit aliquid in genere passionis, sed est in genere relationis".

22 William Paley, Natural Theology (New York (no date)), p. 1. 
have been designed as a much more efficient and structurally organized device ${ }^{23}$. As Haught ${ }^{24}$ and Peacocke ${ }^{25}$ clearly point out, it is ironical that the theory of evolution, that at first seemed to contradict the Divine activity in the Universe, eventually does away with the need to justify the imperfection of the Universe resulting from a faulty Divine design. The observable imperfect created order is not the product of the Divine activity but the operation of the laws of the Universe that manifest the Logos immanent in its structures ${ }^{26}$.

Heller has formulated an incisive argument that, contrary to the classical Aristotelian position, opens up the possibility to consider chance in evolution as a key element of the scientific rationality of the mathematical type ${ }^{27}$. In brief, God could have used chance in the "design" of the Universe. Consequently, the theory of evolution seems to corroborate the epistemological and ontological import of the physical sciences as their theories, namely, the general theory of relativity and quantum mechanics are also considered to be the representations of the rationality immanent in the Universe. This in turn invalidates the metaphor of creation as being the work of an intelligent designer for now it is creation that is "immersed" in the Creator. Such a perspective on the relation between the supernatural and the natural order is referred to as panentheism and has already gained significant support within the contemporary theological reflection ${ }^{28}$. Further theological interpretations of this perspective, which Edwards very gladly subscribes to, follow the intuitions of Urs von Balthasaar and insist on locating the evolving Universe within the relationally constituted Trinity as the Divine kenosis whereby God "backs off" in order to make place for the creation ${ }^{29}$. In this context, God can be properly recognized as acting through the laws of nature with the natural selection as the primary law governing the increase of complexity at the biological level. Also, the creative character of the evolutionary processes occurring within the created order provides some motivation for the revision of the classical attributes of the immutability of $\operatorname{God}^{30}$.

23 Bernard Korzeniewski, Od neuronu do (samo)świadomości (Warszawa: Prószyński i S-ka, 2005), p. 34-36.

24 John Haught, “Darwin's Gift to Theology”, in: Evolutionary and Molecular Biology: Scientific Perspectives of the Divine Action, ed. R.J. Russell, W.R. Stoeger, F.J. Ayala (Vatican and Berkeley, 1998), p. 393-418.

25 Arthur R. Peacocke, Biological Evolution - A Positive Appraisal, in: Evolutionary and Molecular Biology: Scientific Perspectives of the Divine Action, ed. Robert John Russell, William R. Stoeger, Francisco J. Ayala (Vatican and Berkeley, 1998), p. 357-376.

26 Michał Heller, "Scientific Rationality and the Christian Logos", in: Physics, Philosophy and Theology: A Common Quest for Understanding, ed. Robert John Russell, William R. Stoeger, S.J., George V. Coyne, S.J. (Vatican City State: Vatican Observatory, 2000), p. 141-149.

27 Michał Heller, Filozofia przypadku (Kraków, 2014), p. 199-213.

28 Philip Clayton, Arthur R. Peacocke, In Whom We Live and Move and Have Our Being: Panentheistic Reflections on God's Presence in a Scientific World (Michigan-Cambridge U.K.: Grand Rapids, 2014).

29 Hans Urs von Balthasaar, Theo-Drama: Theological Dramatic Theory, Vol. IV: The Action (San Francisco, 1994), p. 327; Jürgen Moltmann, The Way of Jesus Christ: Christology in Messianic Dimensions (London, 1990), p. 274-341.

30 Michael W. Brierley, "Naming a Quiet Revolution: The Panentheistic Turn in Modern Theology”, in: In Whom We Live and Move and Have Our Being: Panentheistic Reflections on God's Presence in a Scientific World, ed. Philip Clayton, Arthur R. Peacocke (Michigan-Cambridge U.K.: Grand Rapids, 2014), p. 1-15. 
The inadequacy of the model of the intelligent design in representing the Divine act of creation receives additional support in the studies carried out in the area of the cognitive science of religion. In particular, the teleological proof comes under scrutiny insofar as the development of the cognitive science of religion seems to indicate that the belief in the existence of the Intelligent Designer based on the ordered structure of reality might result from the specific mode of operation of the human brain. The evolutionary explanations of this state of affairs rely on the two basic cognitive mechanisms called the hyperactive agency detection device (HADD) and the theory of mind (ToM) otherwise called the folk psychology. These mental tools remain in the close relationship in forming beliefs in the intentional agency. The HADD was proposed by Stephen Guthrie and its primary function is to purposely over-interpret the perception of a self-perpelled motion as caused by an intentional agent equipped with mental state ${ }^{31}$ whereby the attack of a predator can be avoided and the reproductive success secured. The theory of mind supplements the workings of the HADD by supplying the array of possible mental processes and motivations that might have led to the behavior perceived ${ }^{32}$.

It turns out, however, that the HADD reveals sensitivity not only to the actual motions of a supposedly minded agent but to the traces of its activity as well ${ }^{33}$. The traces may include easily recognizable objects such as deer trails and bird nests. The human mind has no difficulty in identifying the appropriate agent in such a case. If the encountered trace does not correspond to any familiar mechanical or biological cause, the human mind will likely accept a supernatural agency as the cause of the phenomenon registered. This happens most readily if the investigated trace appears to have a purpose. In other words, the intuitive activity of the human mind cognizing an object that exhibits regularity or design is to explain it in the teleological terms rather than to stipulate the activity of natural causes. This phenomenon has been extensively studied by a psychologist Deborah Kelemen ${ }^{34}$. The studies performed on young children demonstrated a marked preference in explaining a given natural regularity by answering the question "what for?". Consequently, a design or a regularity encountered in nature can be easily clarified as the activity of an intelligent designer and - ultimately - of a creator ${ }^{35}$.

The propensity of the human mind to interpret design and purpose as residuals of the activity of a minded agent correlates with the widespread acceptance and popularity

31 Stewart A. Guthrie, Faces in the Clouds: A New Theory of Religion (New York, 1993). The proper name of the hypersensitive agency detection device was coined out by Barrett: Justin L. Barrett, "Exploring the Natural Foundations of Religion", Cognitive Sciences 4, 1 (2000): 31.

32 Justin L. Barrett, Cognitive Science, Religion and Theology: From Human Minds to Divine Minds (Conshohocken: PA, 2011), p. 73-95.

33 Justin L. Barrett, Why Would Anyone Believe in God? (Lanham: MD, 2004), p, 36-39.

34 Deborah Kelemen, "Why Are Rocks Pointy? Children's Preference for Teleological Explanation of the Natural World”, Developmental Psychology 35, 6 (1999): 1440-1452.

35 Deborah Kelemen, "Are children «intuitive theists»? Reasoning about purpose and design in nature", Psychological Science 15, 5 (2004): 295-301. 
of the Intelligent Design argument (ID) ${ }^{36}$. As it is has been already indicated, it plays a central role in the critique of the theory of evolution with the major claim that the probabilistic character of the evolutionary processes precludes their being designed by an intelligent creator. The cognitive argument discussed above points to two key issues in this context. Firstly, the argument supplements the long list of both methodological and ontological objections to the ID argument, namely, it implies that the belief in the Divine Creator of the Universe based on its observed design and purposefulness is an artifact of the human mind and as such it cannot directly lead to the logical inference of God's existence. The invalidity of this inference stems from the fact that the HADD is an over-sensitive error-management device and may force this inference where it really does not obtain. Also, it tracks the response of the human mind to a primitively conceptualized supernaturality as a counter-intuitive agency. Secondly, the cognitive argument suggests that the intuitive nature of the design and purpose based reasoning will make the uneducated human mind recalcitrant to accept that the perception of a design may not necessarily mean a designer as its cause ${ }^{37}$. Consequently, the aforementioned wish of John Paul II that "science can purify religion from error and superstition" may be much harder to fulfill. However, the precise elucidation of the implications of this conclusion demands a much more thorough investigation.

\section{The doctrine of the original sin}

It is nowadays commonly accepted that the contemporary cosmology yields the most accurate up-to-date explanation of the origins and the evolution of the Universe that radically deflects from their biblical account contained in the opening chapters of the book of Genesis. This fact well correlates with the results of the historical and critical text studies of the first eleven chapters of the book (the biblical prehistory) suggesting that they do not qualify as literary description of the events that they report but their content is a myth-based metaphor serving as a vehicle of fundamental theological truths on the Divine act of creation and the condition of man. Inasmuch as theology seems to be content with the metaphorical character of the Hexaemeron ${ }^{38}$, the literary account of the creation of Adam and Eve ${ }^{39}$ and in particular the story of the fall of Adam ${ }^{40}$ appear to be a highly contentious issue. This stems from the fact that one of the central dogmas of the Catholic faith, that is, the dogma of the original sin hinges upon the historicity of the sin of Adam. Since the cosmic evolution of the entire Universe embraces the evolution of the intelligent life on Earth, it is fitting that this scenario is consequently applied as a scientifically adequate

\footnotetext{
36 Michael Behe, The Darwin's Black Box (New York, 1996).

37 Barrett, Cognitive Science, Religion and Theology: From Human Minds to Divine Minds, p. 70-72.

38 Gn $1,1-2,3$.

39 Gn 2,4-2,25.

40 Gn 3,1-3,24.
} 
background pertinent not only to the creation of the Universe but to the creation of man and his condition as the creature of God as well. The development of the evolutionary theology in this regard will press tremendous challenges onto the commonly accepted and ecclesiastically promulgated tenets of faith concerning the doctrine of the creation of man and the original $\sin ^{41}$.

The teaching of the Catechism of the Catholic Church on the original sin states that the disobedience of Adam resulted in the loss of the sanctifying grace and in the wound of the human nature passed by way of generation onto his descendants due the withdrawal of the Divinely bestowed gift of the supernatural integrity (status naturae elevatae). As a consequence, man was subjected to suffering, mortality, the suppression of the intellectual powers and concupiscence ${ }^{42}$. In contrast to the Protestant position, however, where the depth of this corruption makes the human deeds entirely of no avail for the purpose of salvation, the Catholic doctrine stipulates their efficacy in achieving merits that carry salvific value. The doctrine of the original sin relies on the biblical account of the Book of Genesis as well as on several other biblical references ${ }^{43}$. It was first boldly articulated by St. Augustine and his interpretation has been commonly accepted by the Western Christianity in contradistinction to the East where the interpretation based on the immaturity of the first parents as the cause of the original sin following the teachings of St. Ireneus prevails. The dogmatic declaration of the doctrine of the original sin was given by the Council of Trent in the Decretum super peccato originali4 ${ }^{4}$.

Although from the point of view of the literary style the first eleven chapters of the Book of Genesis do not qualify as historical accounts, the historicity of the Adam's fall has always been taken as true and was as such declared by the Biblical Commission in $1909^{45}$. In his encyclical letter Humani Generis (1950), while demonstrating some openness towards the theory of evolution, Pius XII clearly reaffirmed that the literal character of the biblical account of the original sin must be maintained thus excluding the evolutionarily supported polygenism. This stance is in direct contradiction to monogenism and it challenges the belief in the origin of the human species from one pair directly created by God. The perspective of the reinterpretation of the doctrine of the original sin in light of the ensuing evolutionary picture of the world depends on how much of the literary character of its biblical account in the book of Genesis is to be finally maintained. In order to shed some light on this complex issue, one can easily implement the methodological principle in theology as admitting of the variability of the pictures of the world and

\footnotetext{
41 For an excellent review see: Marcin Majewski, “Grzech pierworodny. Lektura Księgi Rodzaju w kontekście współczesnych nauk przyrodniczych”, in: Mythical Cosmos (Kraków, 2017).

42 The Catechism of the Catholic Church, Art. 396-412.

43 Ps 51,7; Job 14,4; Rm 5,12-21, 1 Cor 15,21-22 where St. Paul introduces the analogy of Christ being the second Adam.

44 The Council of Trient, Sess. V, 1546. DS 789-791.

45 DS 2123.
} 
venture out to investigate how the introduction of the evolutionary picture influences the claims of the theological anthropology.

The projection of the evolutionary picture of the world on the doctrine of the original sin defies this doctrine at two fundamental points in regards to the sin's effects. The first one concerns the aforementioned imperfection of the design brought forth by the workings of the natural selection. In their light, the perfected supernatural state of human nature before the fall seems no longer tenable. If man is indeed a product of evolution, then his imperfect nature prone to suffering and death is not a consequence of the withdrawal of the Divine grace but constitutes part of God's plan of creation resulting from the specificity of the process of evolution with the natural selection as its principal mechanism. As it has been discussed above in detail, evolution does not imply the perfection of an intelligent design but through the workings of the natural selection it leads to the preservation of changes increasing the probability of survival and the reproductive success whereby it brings forth novelty by a slow modification of the existing structures that displays marked imperfection. This imperfection finds its explanation in the specificity of the creative act of God understood as a restraint applied to the Divine essence metaphorically expressed as hewing by the verb bara in the opening sentence of the Book of Genesis $^{46}$. A restraint imposed on a perfect being must result in imperfection.

The second challenge that closely ties with the first is the abandonment of monogenism once the origin of the human species from the common ancestry through evolutionary scenarios is assumed. The detailed studies of the ancestral DNA (the mitochondrial DNA) have led to the conclusion that the origins of the homo sapiens can be traced down to a population inhabiting Africa ca. 150,000 years BC ${ }^{47}$. Although metaphors such as that of the "mitochondrial Eve" have been coined out, no evidence in support of equating it with Eve as the maternal ancestor of all humans can be substantiated ${ }^{48}$. This outcome raises the major issue of the physical death being the result of the neutralization of the state of the naturae elevatae as a consequence of the original sin. If polygenism is to be taken as true, the specificity of the natural selection implies that the physical death must have occurred on Earth before the evolutionary emergence of the human species. The survival of the fittest demands that the population within a given species lacking the proper adaptation must perish. This result allows for a much clearer explanation of the hereditary character of the physical death (destruction) of man not as a consequence of the loss of the gift of integrity but as a shared condition that is common to the entirety of creation both animate and inanimate.

46 Ellen Van Wolde, "Why the verb ארב does not mean to create in Genesis 1.1-2.4a", Journal for the Study of the Old Testament 34, 1 (2009): 3-23.

47 K.A. Cyran, M. Kimmel, “Alternatives to the Wright-Fisher model: The robustness of mitochondrial Eve dating”, Theoretical Population Biology 78, 3 (2010): 165-172.

48 P. Awadalla, A. Eyre-Walker, J.M. Smith, "Linkage Disequilibrium and Recombination in Hominid Mitochondrial DNA", Science 286 (1999): 2524-2525. 
It turns out that the evolutionary and cognitive sciences provide natural explanations not only of the physical evil (corruption) but the moral evil as well. There exists a vast body of research on the evolutionary origins of morality ${ }^{49}$. The morality of humans originates from the cumulative operation of the so called moral instincts which developed as the result of the natural selection exerting its influence over a vast period of time. These instincts include on one hand empathy, cooperation and justice, on the other, however, egoism, jealousy, fear and lust on the other. This results in a marked dissonance between the desire of good and the proclivity towards evil indicating a natural source of the internal disharmony of the human nature and the two opposing forces governing the human behavior. Also, since these instincts evolved prior to the rational reasoning they may effectively compete with the outcomes of this reasoning in the decision making processes. Consequently, the inclination towards the moral evil does not have to be viewed as the result of the loss of the Divine gift of integrity but as a natural biological endowment which has been built into the human nature over the vast time span of the evolution of the human species. In such a case, the moral guilt for the original sin does not find its proper justification.

The contemporary theology has been generating numerous responses to the challenges that the theory of evolution and the cognitive sciences project on the doctrine of the original sin. For the most part, these responses aim at achieving a compromise between the preservation of the integrity of the dogma and, at the same time, embedding it in the context of the scientific picture of the world. Majewski points out that the prevailing understanding of the original sin departs from the strict traditional where Adam's sin is conceived as a personal transgression of the Divine command by an authentic historical figure. Instead, a more global and structural view is preferred. In the most general approach, two distinct theological proposals on how to reinterpret the doctrine of the original sin can be singled out. While retaining the reality of the transgression, the first of them uses the shift of responsibility for the sin to a group of individuals in order to assure reconciliation with the evolutionarily motivated polygenism. This proposal gains its support in the works of such scholars as, for instance, Rahner ${ }^{50}$, Girard and Schwager ${ }^{51}$ and Edwards $^{52}$. The second proposal, however, adopts a more radical approach in which the factuality of the transgression, be it personal or collective, is entirely absent and the biblical account of the fall of Adam serves as a complex metaphor of the experienced state

49 Patricia Churchland, Moralność mózgu. Co neuronauka mówi o moralności (Kraków, 2013); Frans de Waal, Matpy i filozofowie. Skad pochodzi moralność? (Kraków, 2013); Frans de Waal, Bonobo i ateista. W poszukiwaniu humanizmu wśród naczelnych (Kraków, 2014).

50 Karl Rahner, “Erbsünde und Evolution”, Concilium 3 (1967): 459-465.

51 For reviews of Girard's and Schwager’s postions see: Stanisław Budzik, “Teologia a obraz człowieka na przykładzie antropologii Rene Girarda", in: Obrazy świata w teologii i naukach przyrodniczych, ed. Michał Heller, Stanisław Budzik. Stanisław Wszołek (Tarnów, 1996), p. 227-252; Stanisław Budzik, "Czy teoria ewolucji potwierdza naukę o grzechu pierworodnym? Model Raymunda Schwagera”, Analecta Cracoviensia 33 (2001): 360-362.

52 Edwards, Bóg ewolucji: teologia trynitarna, p. 87-110. 
of imperfection of the created order only. The standpoints of de Chardin ${ }^{53}$, Hefner $^{54}$ and Życiński ${ }^{55}$ are representative for this proposal. The evident discrepancy between these two proposals suggests that the reinterpretative efforts still face fundamental challenges with the possible indication that much needs to be done to ascertain what the theological invariants of the doctrine of the original sin truly amount to.

\section{Does ruthless evolution cause evil and suffering?}

The problem of how to reconcile the goodness and the omnipotence of God with the existence of suffering and evil has been central to both philosophical and theological discussion since the times of antiquity. The famous formulation of Epicurus in the 4th century $\mathrm{BC}$ has been boldly restated by David Hume in the 18th century: "Is God willing to prevent evil but unable to do so? Then he is not omnipotent. Is God able to prevent evil but unwilling to do so? Then he is malevolent (or at least less than perfectly good). If God is both willing and able to prevent evil then why is there evil in the world?"56. Numerous answers were given within the time in between as well as following Hume's statement and the problem remains unresolved until today. For reasons that will become obvious in the course of this consideration, the classical response of St. Augustine on the nature of evil is of particular importance. In the effort to circumvent the Manichean conviction on the ontological reality of evil, St. Augustine resorts to the fundamental distinction between the necessary and the contingent being and states that contingent beings must be subject to corruption due to their inherent imperfection ${ }^{57}$. Consequently, corruption is not in itself evil but is the neutralization of good only. Such state of affairs is the consequence of the Divine creative act represented by the aforementioned metaphor of hewing where the ensuing imperfection of the created order implies that things created are not eternal in their existence.

The process of the Darwinian evolution with the natural selection as its principal mechanism is commonly perceived as a ruthless and blind law of nature that sacrifices the adaptively disadvantaged portion of a given population for the sake of those that had the luck to be better predisposed for the actual changes of the conditions of the environment and subsequently managed to reproduce. In his account of the impact of the evolutionary theory on the natural theology Edwards takes up the much debated theme of evil and suffering from a very interesting and promising point of view ${ }^{58}$. Instead of finding a solution

\footnotetext{
53 For a review of de Chardin's position on the original sin see: Józef Kulisz, „Grzech pierworodny w rozumieniu P. Teilharda de Chardin", Collectanea Theologica 55 (1985): 45-59.

54 Philip Hefner, The Human Factor. Evolution, Culture, Religion (Minneapolis: MI, 1993), p. 55f.

55 Józef Życiński, “Antropologiczny sens prawdy o grzechu pierworodnym”, access 13.11.2017, http://pracownik. kul.pl/files/12979/public/Zycinski_grzech.doc.

56 David Hume, Dialogues concerning Natural Religion and Other Writings (1779), ed. Dorothy Coleman (Cambridge, 2007).

57 Augustine, Confessions, Book VII.

58 Edwards, Bóg ewolucji: teologia trynitarna, p. 56-59.
} 
in which suffering is invariably assumed as an absolute reality, he cleverly points to the possibility in redefining the concept of suffering by questioning its objectivity from the perspective of natural sciences. Firstly, he makes reference to neurobiology by observing that the experience of suffering is attributed to the living organisms with highly developed brains and nervous systems. After all, there exists a close evolutionary proximity between the brains of conscious human beings and other living organisms. By reaching to some general remarks by Daniel Dennet, Edwards acutely suggests that the subjective experience of suffering by humans may become a powerful anthropomorphism that is easily applied to processes that involve corruption.

Since Edwards does not expand on the scientific account of suffering any longer, it is worthwhile to treat this issue in a bit more detail in order to support his intuitions and open up new perspectives. The sensation of pain, which is the main cause of suffering, is a quale that is accessible only subjectively (introspectively) in the first person ontology. Qualia (in plural) constitute the so called hard problem of consciousness considered by some to be out of reach of the scientific methodology ${ }^{59}$. As it has been indicated in the previous section, the human mind is equipped with a special module called ToM (theory of mind) that attributes mental states to agents exhibiting certain kinds of behavior. It seems rational to expect that by registering behaviors of living organisms interpreted by the human mind as fear or trembling, the mental states corresponding to pain and suffering experienced by these organisms would be used as the possible explanations of these behaviors ${ }^{60}$. Consequently, the introspectively accessible experience of suffering could be attributed to beings in a manner of a strict anthropomorphism that may not have much foundation in reality. Following the standpoint of Haught, Edwards stipulates that, with the universality of suffering thus challenged, the natural selection can be perceived similarly to all other laws of nature not as evil but as a valuable creative process that through corruption (including death) brings forth novelty with the higher degree of complexity ${ }^{61}$. As a result, the problem of suffering becomes the problem of anthropology and not the natural theology. Since death as a form of corruption had been an indispensable part of the animated life long before the emergence of the conscious human species, the perception of death as a source of suffering is posterior in the evolutionary scenarios with respect to the physical death understood as the termination of life. The human experience of suffering seems to be rather an exception than a rule within the entirety of the animated life both in the diachronic and synchronic perspective.

Evolution causes corruption which agrees with the fact that all creation is contingent, that is, its lifespan is limited, it will cease to exist at some point, it will die a physical death. This is necessary for the newness of life to occur. As it was shown above corrup-

59 David Chalmers, "Facing up to the problem of consciousness", Journal of Consciousness Studies 2, 3 (1995): 200-219.

60 E. Bruneau, A. Pluta, R. Saxe, "Distinct roles of the «Shared Pain» and «Theory of Mind» networks in processing others' emotional suffering”, Neuropsychologia 50 (2011): 219-231.

61 Edwards, Bóg ewolucji: teologia trynitarna, p. 60-61. 
tion may be anthropomorphically associated with suffering leading to the incorrect inference that corruption implies massive suffering in the Universe. It looks like Edwards may be succumbing to the same error he has just warned about. He rightly states that there must be some correspondence between the nature of the Divine action as manifested in Jesus Christ, the Logos permeating the created order, and the Divine action exercised through the workings of the natural selection. In other words, it seems rational that Logos would undergo corruption exemplified by the death on the Cross.

What strikes as inconsistent, however, is that Edwards instantly switches from speaking about corruption to the discourse on suffering whereby he immediately ends up with the Divine attributes such as merciful and compassionate. This is a blatant anthropomorphization that serves as an easy justification of how God suffers together with his corruptible creation. Of course, one can legitimately talk about the Divine kenosis (vide supra) evident not only in creation but in incarnation and crucifixion. This does not mean, however, that it is driven by the Divine compassion with creation but with the Divine concorruption only. This exaggerated emphasis on suffering supported, as Edwards relates, by many contemporary theologians ${ }^{62}$, leads to a very pessimistic tone of the theological expression that challenges the classical conviction on the Divine omnipotence. This tone could be greatly altered by shifting its weight to the newness of life that springs out of corruption thus giving theology its positive splendor. Consequently, by minimizing the impact of suffering one can restore the idea of the omnipotent God within the framework proposed by Duns Scotus where the potentia absoluta and the potentia ordinata are distinguished. The potentia ordinata manifests itself within the contingent being with the natural selection involving corruption as one of the primary mechanism of bringing forth complexity in the Universe. It remains in no contradiction to the Divine omnipotence represented by the potentia absoluta.

At this point it seems fitting to suggest that such an approach greatly favors altruism and tames down selfishness as it invites the abandonment of suffering - Induced anthropocentrism and personal benefits in favor of the self-giving for the creative newness of life. Surprisingly enough, this is a genuinely evangelical truth as it directly reflects the parable of the seed of wheat ${ }^{63}$. In its light, the physical death does not have to be viewed as a tragic end but a beginning of a new and better reality. The process of perishing for the purpose of bringing forth life seems to be a common characteristics that unites the natural processes with the supernatural destination of man. In such a perspective, the relation between the natural and the supernatural seems to be in need of reconsideration as well as it brings unexpectedly close the natural dynamics with the dynamics of achieving supernaturality as the principal goal of man. This greatly accords with what St. Paul writes in his letter to the Romans: "For the creation was subjected to futility, not of its own will, but

62 Edwards, Bóg ewolucji: teologia trynitarna, p. 65-70.

$63 \mathrm{~J} 12,24$. 
because of Him who subjected it, in hope that the creation itself also will be set free from its slavery to corruption into the freedom of the glory of the children of God"64.

\section{Summary}

As the course of the analysis carried out in this study comes to a close, one gets an inevitable impression that the issues raised and discussed within the study's confines are far from being settled and the certitude routinely celebrated in theology has suddenly evaporated from one's investigative gaze. This intriguing outcome correlates with the precise sense of the theological paradigm which in its original meaning developed within the history of science by Thomas Kuhn. It remains beyond doubt that theology has been experiencing an array of anomalies in confrontation with the scientific picture of the world which is indicative that its conceptual foundation is in the deep and urgent need of strengthening so that these anomalies may receive their proper resolution. By the introduction of the evolutionary picture of the world in particular, a number of theological tenets such as of the original sin, for instance, face the necessity of in-depth reformulation and reinterpretation in order to discriminate what are the theological invariants that they carry, that is, the revealed content, and what constitutes the man-made vehicle of these invariants. The Catholic Catechism of the Church suggests a telling distinction to reflect this fact into Tradition - with the capital $\mathrm{T}$, and tradition with the small $\mathrm{t}^{65}$.

Although revolutions have been rather unwelcome in theology, the shift of the paradigm from the static pre-scientific to the dynamic evolutionary clearly causes such a revolution. This calls for a major reconsideration of the rationality of the development of doctrine, that is, the precise rules that govern this development. In the first approximation, the revolution could be associated with the hermeneutics of rupture resulting in the breach of the theological rationality. In order to secure the integral and invariable character of theology, however, the hermeneutics of continuity is preferred where the theological rationality is understood as the accumulation of the invariable deposit of faith and the discontinuities play only accidental role ${ }^{66}$. The adequate picture that can be preliminarily inferred from this study suggests a more complex nature of the rationality of the development of theology in which both the hermeneutics of continuity and the hermeneutics of rupture dynamically contribute to this process in a constitutive and constructive way. In short, they both equally belong to the "rules of the game". Interestingly enough, such a model of the rationality of the scientific growth was proposed by Michał Heller and it relies on the non-linear theory of dynamic systems ${ }^{67}$.

\footnotetext{
$64 \operatorname{Rm} 8,20-21$.

65 The Catechism of the Catholic Church, Art. 83.

66 Benedict XVI, Sacramentum caritatis, Art. 3.

67 Michał Heller, "Nieliniowa ewolucja nauki”, Roczniki filozoficzne KUL 22 (1984): 105-125.
} 
The aforementioned shift of the theological paradigm points to the necessity of a more fundamental change of the epistemological foundations of theology from the epistemic mode where theological expression enjoys absolute certainty and objectivity to the doxatic mode where only probable knowledge is possible ${ }^{68}$. It must be remembered that despite of the widespread application of the theory of evolution in a variety of scientific disciplines, the theory falls under the regime of the scientific method and, hypothetically, it may be in future replaced by a theory that more accurately explains the observed phenomena. In such a case, theology should also respond with the appropriate reformulation of its doctrine. Although much more fundamental studies need to be carried in order to precisely justify this process, the development of theological doctrine of the Church appears a lot more complex and dynamic where anomalies and fluctuations play a central role as compared to the static growth set forth by the hermeneutics of continuity.

\section{Bibliography}

Augustine. Confessions.

Augustine. De Genesi ad litteram I.

Awadalla, P., A. Eyre-Walker, J.M. Smith. "Linkage Disequilibrium and Recombination in Hominid Mitochondrial DNA". Science 286 (1999): 2524-2525.

Ayala, Francisco J. Dar Karola Darwina dla nauki i religii. Warszawa, 2009.

Barbour, Ian G. Mity, modele, paradygmaty. Kraków, 1984.

Barrett, Justin L. Cognitive Science, Religion and Theology: From Human Minds to Divine Minds. Conshohocken: PA, 2011.

Barrett, Justin L. Why Would Anyone Believe in God?. Lanham: MD, 2004.

Basil. De legendis libris Gentilium.

Behe, Michael. The Darwin's Black Box. New York, 1996.

Benedict XVI. Sacramentum caritatis.

Brierley, Michael W. "Naming a Quiet Revolution: The Panentheistic Turn in Modern Theology". In: In Whom We Live and Move and Have Our Being: Panentheistic Reflections on God's Presence in a Scientific World, ed. Philip Clayton, Arthur R. Peacocke, p. 1-15. Michigan-Cambridge U.K.: Grand Rapids, 2014.

Bruneau, E.G., A. Pluta, R. Saxe. "Distinct roles of the «Shared Pain» and «Theory of Mind» networks in processing others' emotional suffering". Neuropsychologia 50 (2011): 219-231.

Budzik, Stanisław. “Czy teoria ewolucji potwierdza naukę o grzechu pierworodnym? Model Raymunda Schwagera”. Analecta Cracoviensia 33 (2001): 360-362.

Budzik, Stanisław. "Teologia a obraz człowieka na przykładzie antropologii Rene Girarda". In: Obrazy świata $w$ teologii i naukach przyrodniczych, ed. Michał Heller, Stanisław Budzik. Stanisław Wszołek, p. 227-252. Tarnów, 1996.

68 Józef Życiński, „Posłowie”, in: Ian G. Barbour, Mity, modele, paradygmaty (Kraków, 1984), p. $235-261$. 
Chalmers, David. "Facing up to the problem of consciousness". Journal of Consciousness Studies 2, 3 (1995): 200-219.

Churchland, Patricia. Moralność mózgu. Co neuronauka mówi o moralności. Kraków, 2013.

Clayton, Philip, Arthur R. Peacocke. In Whom We Live and Move and Have Our Being: Panentheistic Reflections on God's Presence in a Scientific World. Michigan-Cambridge U.K.: Grand Rapids, 2014.

Cyran, K.A., M. Kimmel. "Alternatives to the Wright-Fisher model: The robustness of mitochondrial Eve dating". Theoretical Population Biology 78, 3 (2010): 165-172.

Dawkins, Richard. The God Delusion. London-Toronto-Sydney-Auckland-Johannesburg, 2006.

De Waal, Frans. Bonobo i ateista. W poszukiwaniu humanizmu wśród naczelnych. Kraków, 2014.

De Waal, Frans. Matpy i filozofowie. Skąd pochodzi moralność?. Kraków, 2013.

Edwards, Denis. Bóg ewolucji: teologia trynitarza. Kraków, 2016.

French, Steven. The Structure of the World: Metaphysics and Representation. Oxford University Press: Oxford, 2014.

Gregersen, Niels Henrik. "Evolutionary theology". In: Encyclopedia of Sciences and Religions, ed. Anne L.C. Runehov, Lluis. Oviedo, Dordecht, p. 809-817. Netherlands, 2013.

Guthrie, Stewart A. Faces in the Clouds: A New Theory of Religion. New York, 1993.

Haught, John F. Darwin's Gift to Theology, in: Evolutionary and Molecular Biology: Scientific Perspectives of the Divine Action, ed. Robert John Russell, William R. Stoeger, Francisco J. Ayala. Vatican and Berkeley, 1998.

Haught, John F. Theology After Darwin: A Theology of Evolution. Boulder: CO, 2008.

Hefner, Philip. The Human Factor. Evolution, Culture, Religion. Minneapolis: MI, 1993.

Heller, Michał. "Naukowy obraz świata a zadanie teologa". In: Obrazy świata $w$ teologii $i$ w naukach przyrodniczych, ed. Michał Heller, Stanisław Budzik, Stanisław Wszołek, p. 13-27. Tarnów, 1996.

Heller, Michał. "Nieliniowa ewolucja nauki”. Roczniki filozoficzne KUL 22 (1984): 105-125.

Heller, Michał. "Scientific Rationality and the Christian Logos". In: Physics, Philosophy and Theology: A Common Quest for Understanding, ed. Robert John Russell, William R. Stoeger, S.J., George V. Coyne, S.J., p. 141-149. Vatican City State: Vatican Observatory, 2000.

Heller, Michał. "The field of rationality and category theory". In: Mathematical Structures of the Universe, ed. Michał Eckstein, Michał Heller, Sebastian Szybka, p. 441-457. Kraków, 2014.

Heller, Michał. Filozofia przypadku. Kraków, 2014.

Heller, Michał. Uchwycić przemijanie. Kraków, 1997.

Hume, David. Dialogues concerning Natural Religion and Other Writings (1779), ed. Dorothy Coleman. Cambridge, 2007.

John Paul II. "A Letter to the Reverend George V. Coyne, S.J, Director of the Vatican Observatory". In: Physics, Philosophy and Theology: A Common Quest for Understanding, ed. Robert John Russell, William R. Stoeger, S.J., George V. Coyne, S.J., p. M1-M14. Vatican City State: Vatican Observatory, 2000. 
Kasper, Walter. The God of Jesus Christ. New York, 1976.

Kelemen, Deborah. "Are children «intuitive theists»? Reasoning about purpose and design in nature". Psychological Science 15, 5 (2004): 295-301.

Kelemen, Deborah. "Why Are Rocks Pointy? Children's Preference for Teleological Explanation of the Natural World”. Developmental Psychology 35, 6 (1999): 1440-1452.

Korzeniewski, Bernard. Od neuronu do (samo)świadomości. Warszawa: Prószyński i S-ka, 2005.

Kulisz, Józef. "Grzech pierworodny w rozumieniu P. Teilharda de Chardin". Collectanea Theologica 55 (1985): 45-59.

Liana, Zbigniew. "Teologia a naukowe obrazy świata”. In: Wiara i nauka, ed. J. Mączka, p. 69-90. Kraków 2010.

Majewski, Marcin. "Grzech pierworodny. Lektura Księgi Rodzaju w kontekście współczesnych nauk przyrodniczych”. In: Mythical Kosmos. Kraków, 2017.

Moltmann, Jürgen. The Way of Jesus Christ: Christology in Messianic Dimensions. London, 1990.

Paley, William. Natural Theology. New York (no date).

Peacocke Arthur R. "Biological Evolution - A Positive Appraisal". In: Evolutionary and Molecular Biology: Scientific Perspectives of the Divine Action, ed. Robert John Russell, William R. Stoeger, Francisco J. Ayala, p. 357-376. Vatican and Berkeley, 1998.

Rahner, Karl. "Anthropologie (theologische)". In: Lexikon für Theologie und Kirche, ed. Josef Höfer, Karl Rahner, col. 618-627. Freiburg/Br. 1957-67.

Rahner, Karl. "Erbsünde und Evolution”. Concilium 3 (1967): 459-465.

The Catechism of the Catholic Church.

Thomas Aquinas. De Potentia Dei.

Thomas Aquinas. Summa Contra Gentiles.

Thomas Aquinas. Summa Theologiae.

Turek, Józef. "Filozoficzno-światopoglądowe implikacje dynamicznego obrazu wszechświata”. In: Obrazy świata w teologii i w naukach przyrodniczych, ed. Michał Heller, Stanisław Budzik, Stanisław Wszołek, p. 125-145. Tarnów, 1996.

Vatican II. Dei Verbum.

Van Wolde, Ellen. "Why the verb ארב does not mean to create in Genesis 1.1-2.4a". Journal for the Study of the Old Testament 34, 1 (2009): 3-23.

Von Balthasaar, Hans Urs. Theo-Drama: Theological Dramatic Theory. Vol. IV: The Action. San Francisco, 1994.

Wildman, Wesley J., Robert John Russell. "Chaos: A Mathematical Introduction with Philosophical Reflections". In: Chaos and Complexity: Scientific Perspectives on Divine Action, ed. Robert John Russell, Nancey Murphy, Arthur R. Peacocke, p. 49-90. Vatican City State, 1995.

Życiński, Józef. “Antropologiczny sens prawdy o grzechu pierworodnym”. Access 13.11.2017. http://pracownik.kul.pl/files/12979/public/Zycinski_grzech.doc.

Życiński, Józef. “Posłowie”. In: Ian G. Barbour, Mity, modele, paradygmaty, p. 235-261. Kraków, 1984. 


\begin{abstract}
The evolutionary theology is a new branch of theology in which the dynamic picture of the origin and development of life in Universe by means of the adaptive processes governed by the natural selection is considered to be the adequate ontological foundation. The presented paper surveys the challenges that the implementation of the evolutionary ontology presses upon selected basic theological issues: methodology of theology, natural theology, the doctrine of the original sin and the problem of suffering and evil. It will be argued that the large extent of the expected modifications within the theological expression as the dynamic ontology is introduced qualifies as the change of the theological paradigm similarly to how the changes of the paradigms in sciences lead to the scientific revolutions. Finally, a novel model of the rationality of the development of the theological doctrine will be proposed where the hermeneutics of continuity and the hermeneutics of rupture are not in opposition but they contribute to the overall rationality as its complementary constitutive principles.
\end{abstract}

Keywords: evolution, paradigm, rationality, original sin, evil, suffering, hermeneutics

\title{
Streszczenie
}

\section{CO JEST NIEZMIENNE? O MOŻLIWOŚCI I PERSPEKTYWACH TEOLOGII EWOLUCYJNEJ}

Teologia ewolucyjna jest nowym obszarem w teologii, w którym zakłada się, że dynamiczny obraz początku i rozwoju życia we Wszechświecie, oparty na rządzonych doborem naturalnym scenariuszach adaptacyjnych, stanowi właściwą ontologiczną podstawę. Przedstawiona praca zawiera przegląd wyzwań, jakie wprowadzenie ewolucyjnego obrazu stawia wybranym problemom teologicznym: metodologii teologii, teologii naturalnej, doktrynie o grzechu pierworodnym oraz problemowi zła i cierpienia. W trakcie prowadzonych rozważań argumentowane jest, że skala oczekiwanych modyfikacji w ekspresji teologicznej wraz z wprowadzeniem dynamicznej ontologii kwalifikuje się jako zmiana teologicznego paradygmatu podobnie jak zmiana paradygmatu w nauce prowadzi zgodnie z koncepcją Thomasa Kuhna do naukowej rewolucji. Ostatecznie, zaproponowany został nowy model racjonalności rozwoju doktryny teologicznej, w którym hermeneutyka ciągłości i zerwania nie stoją w stosunku do siebie w opozycji, ale stanowią dla tej racjonalności jej dwie komplementarne składowe.

Słowa kluczowe: ewolucja, paradygmat, racjonalność, grzech pierworodny, zło, cierpienie, hermeneutyka 